\title{
Formulasi Terhadap Sistematika Akta Dalam Akad Syariah Yang Berkepastian Hukum
}

\author{
Ady Setyo Fardiyanto \\ Magister Kenotariatan Fakultas Hukum Univrsitas Islam Indonesia Yogyakarta Indonesia \\ Jln. Cik Di Tiro No. 1 Yogyakarta 55223 Indonesia \\ adysetyof@gmail.com
}

\begin{abstract}
This study aims to describe and analyze the juridical implications of the validity of the deed made by the Notary related to the addition of the Qur'anic verse, as well as the formulation of the systematic deed in the sharia contract with legal certainty. The type of research used is empirical juridical research. The approach used is statutory and a case approaches, with qualitative descriptive analysis. The results of this study conclude that first, the use of such verses of the Qur'an does not violate the provisions of the legislation if it is placed at the beginning of the contents of the deed or at the end of the premise. That the beginning and end of the deed is absolutely the responsibility of the Notary. However, the content of the deed is a written agreement desired by the parties. As long as it is based on the applicable laws and regulations. Second, the making of sharia banking deeds made in the form of a notary deed must be made in the form of a notary deed in accordance with the formalities of a notary deed as regulated in Article 38 of the Notary Position Act. If there are procedures that are not fulfilled, the deed with a court process can be declared as a deed that has the power of proof under the hand. If the parties or clients request to add verses of the Qur'an to the notary deed, it is necessary to pay attention to the notary in placing the verse so that it does not violate the provisions of Article 38 of the Notary Position Act.
\end{abstract}

Key Words: Notary deed; notary office law; sharia banking deed

\begin{abstract}
Abstrak
Penelitian ini bertujuan untuk mendeskripsikan dan menganalisis mengenai implikasi yuridis terhadap keabsahan akta yang dibuat oleh Notaris terkait dengan penambahan ayat al-Qur'an, serta formulasi mengenai sistematika akta dalam akad syariah yang berkepastian hukum. Jenis penelitian yang digunakan adalah penelitian yuridis empiris. Pendekatan yang digunakan adalah pendekatan perundang-undangan dan pendekatan kasus, dengan analisis deskriptif kualitatif. Hasil penelitian ini menyimpulkan, pertama, penggunaan ayat-ayat al-Qur'an demikian tidak melanggar ketentuan perundang-undangan apabila diletakkan pada awal isi akta atau pada akhir premisse. Bahwa awal dan akhir akta mutlak merupakan tanggungjawab Notaris. Namun untuk isi akta merupakan kesepakatan tertulis yang dikehendaki oleh para pihak. Sepanjang berdasarkan peraturan perundangundangan yang berlaku. Kedua, pembuatan akta-akta perbankan syariah yang dibuat dalam bentuk akta Notaris harus dibuat dalam bentuk akta Notaris sesuai dengan formalitas akta Notaris yang diatur dalam Pasal 38 Undang-Undang Jabatan Notaris. Apabila ada prosedur yang tidak dipenuhi, akta tersebut dengan proses pengadilan dapat dinyatakan sebagai akta yang mempunyai kekuatan pembuktian di bawah tangan. Apabila para pihak atau klien meminta untuk ditambahkannya ayat alQur'an ke dalam akta Notaris maka perlu diperhatikan oleh Notaris di dalam penempatan ayat tersebut supaya tidak menyalahi ketentuan Pasal 38 Undang-Undang Jabatan Notaris..
\end{abstract}

Kata-kata Kunci: Akta notaris; akta perbankan syariah; undang-undang jabatan notaris 


\section{Pendahuluan}

Sejak awal 70-an, gerakan Islam di tingkat nasional telah memasuki bidang ekonomi dengan diperkenalkannya sistem ekonomi Islam, sebagai alternatif terhadap sistem kapitalis dan sistem sosialis. Wacana ekonomi Islam itu diawali dengan konsep ekonomi dan bisnis non-ribawi. Namun dewasa ini terkesan bahwa ekonomi Islam itu identik dengan konsep keuangan dan perbankan. ${ }^{1} \mathrm{Di}$ Indonesia, bank syariah ${ }^{2}$ yang pertama didirikan pada 1992 adalah Bank Muamalat Indonesia (BMI). Walaupun perkembangannya agak terlambat bila dibandingkan dengan negara-negara muslim lainnya, perbankan syariah di Indonesia akan terus berkembang.

Indonesia yang mayoritas masyarakatnya beragama Islam sudah sejak lama mendamba-dambakan suatu lembaga keuangan yang proses transaksinya mengacu pada aturan syariah (hukum Islam). Sejak diberlakukannya UndangUndang Nomor 7 Tahun 1992 tentang Perbankan, maka keberadaan bank syariah dalam sistem perbankan di Indonesia sebenarnya telah diakui dan dikenal. Bahkan dapat dikatakan bahwa Undang-Undang Nomor 7 Tahun 1992 ini merupakan pintu gerbang dimulainya perbankan syariah di Indonesia. Namun demikian, undang-undang tersebut belum memberikan landasan hukum yang cukup kuat terhadap pengembangan bank syariah. ${ }^{3}$ Hingga 1998, dengan diberlakukannya Undang-Undang Nomor 10 Tahun 1998 tentang Perubahan Undang-Undang Nomor 7 Tahun 1992 tentang Perbankan yang diikuti dengan dikeluarkannya sejumlah ketentuan pelaksanaan dalam bentuk Surat Keputusan (SK) Direksi Bank Indonesia, baru kemudian dianggap telah memberikan landasan hukum yang lebih kuat dan kesempatan yang lebih luas bagi pengembangan perbankan syariah di Indonesia. Perundang-undangan tersebut memberikan kesempatan yang lebih luas untuk pengembangan jaringan perbankan syariah.

Sejak 1998 sampai dengan akhir 2004 dapat dikatakan merupakan masa booming pertumbuhan perbankan syariah. Sampai akhir 2004, Bank Indonesia telah menerbitkan 17 regulasi mulai dari kelembagaan (Bank Umum dan BPR Syariah), prinsip kehati-hatian (kualitas aktiva produktif, pencadangan

\footnotetext{
${ }^{1}$ Berdasarkan ketentuan Pasal 1 angka 1 Undang-Undang Nomor 10 Tahun 1998 tentang Perubahan Atas Undang-Undang Nomor 7 Tahun 1992 tentang Perbankan menyebutkan pengertian perbankan adalah segala sesuatu yang menyangkut tentang bank, mencakup kelembagaan, kegiatan usaha, serta cara dan proses dalam melaksanakan kegiatan usahanya.

${ }^{2}$ Berdasarkan ketentuan Pasal 1 angka 7 Undang-Undang Nomor 21 Tahun 2008 tentang Perbankan Syariah menyebutkan pengertian bank syariah adalah bank yang menjalankan kegiatan usahanya berdasarkan prinsip syariah dan menurut jenisnya terdiri atas Bank Umum Syariah dan Bank Pembiayaan Rakyat Syariah.

${ }^{3}$ Amir Mahmud dan Rukmana, Bank Syariah Teori, Kebijakan, dan Studi Empiris di Indonesia, Erlangga, Jakarta, 2010, hlm. 11.
} 
penghapusan aktiva produktif), pasar keuangan dan instrumen moneter (kliring, GWM, pasar uang antar bank syariah, fasilitas pinjaman jangka pendek bank syariah, Sertifikat Wadiah Bank Indonesia), dan laporan bulanan (Bank Umum dan BPR Syariah secara on-line). ${ }^{4}$ Kemudian di 2008, pemerintah mengeluarkan regulasi yang mengatur sepenuhnya tentang perbankan syariah di Indonesia melalui Undang-Undang Nomor 21 Tahun 2008 tentang Perbankan Syariah.

Perkembangan lembaga keuangan syariah (bank syariah) di Indonesia yang kemudian diimbangi dengan kebijakan pemerintah yang mengeluarkan regulasi yang mengaturnya, juga harus didukung oleh instrumen-instrumen penunjang yang terkait dengan segala aktifitas kegiatan perbankan syariah. Salah satu instrumen tersebut ialah Notaris, dimana Notaris dalam kontrak bisnis termasuk bisnis syariah memilik peran yang penting mengingat tugas pokoknya membuat akta-akta otentik yang diperlukan sebagai alat bukti telah terjadinya peristiwa hukum. ${ }^{5}$

Negara Republik Indonesia sebagai negara hukum berdasarkan Pancasila dan Undang-Undang Dasar Negara Republik Indonesia Tahun 1945 menjamin kepastian, ketertiban, dan perlindungan hukum bagi setiap warga negara. Untuk menjamin kepastian, ketertiban, dan perlindungan hukum dibutuhkan alat bukti tertulis yang bersifat otentik mengenai perbuatan, perjanjian, penetapan, dan peristiwa hukum yang dibuat di hadapan atau oleh pejabat yang berwenang. ${ }^{6}$ Tidak terkecuali juga terhadap produk-produk ekonomi yang menggunakan prinsip syariah. ${ }^{7}$

Notaris menduduki posisi yang sangat penting dalam industri perbankan syariah saat ini, karena Notaris memiliki peranan dalam pembuatan akta-akta kontrak-kontrak produk perbankan syariah dan pengikatan jaminan (khususnya dalam perkara hak tanggungan dan fidusia). Undang-Undang Nomor 2 Tahun 2014 tentang Perubahan Atas Undang-Undang Nomor 30 Tahun 2004 tentang Jabatan Notaris menyatakan bahwa, "Notaris adalah pejabat umum yang berwenang untuk membuat akta otentik dan memiliki kewenangan lainnya sebagaimana dimaksud dalam undang-undang ini atau berdasarkan undangundang lainnya."8

\footnotetext{
${ }^{4}$ Direktorat Perbankan Syariah Bank Indonesia, Laporan Perkembangan Perbankan Syariab Tabun 2004, Bank Indonesia, Jakarta, 2004, hlm. 73.

${ }^{5}$ Saifuddin Arief, Notariat Syariah Dalam Praktik, Darunnajah Publishing, Jakarta, 2011, hlm. 36.

${ }^{6}$ Muhammad Luthfan Hadi Darus, Hukum Notariat dan Tanggung Jawab Jabatan Notaris, UII Press, Yogyakarta, 2017, hlm. 1

${ }^{7}$ Berdasarkan ketentuan Pasal 1 angka 12 Undang-Undang Nomor 21 Tahun 2008 tentang Perbankan Syariah menyebutkan prinsip syariah adalah prinsip hukum Islam dalam kegiatan perbankan berdasarkan fatwa yang dikeluarkan oleh lembaga yang memiliki kewenangan dalam penetapan fatwa di bidang syariah.

${ }^{8}$ Berdasarkan ketentuan Pasal 1 angka 1 Undang-Undang Nomor 2 Tahun 2014 tentang Perubahan Atas Undang-Undang Nomor 30 Tahun 2004 tentang Jabatan Notaris.
} 
Kebutuhan akan jasa Notaris dalam masyarakat modern tidak mungkin dihindarkan. Notaris sebagai pejabat umum diangkat oleh pemerintah dan pemerintah sebagai organ negara mengangkat Notaris bukan semata untuk kepentingan Notaris itu sendiri, melainkan juga untuk kepentingan masyarakat luas. Jasa yang diberikan oleh Notaris terkait erat dengan persoalan trust (kepercayaan antara para pihak), artinya negara memberikan kepercayaan yang besar terhadap Notaris dan dengan demikian dapat dikatakan bahwa pemberian kepercayaan kepada Notaris berarti Notaris tersebut mau tidak mau telah dapat dikatakan memikul pula tanggungjawab atasnya. Tanggungjawab ini dapat berupa tanggungjawab secara hukum maupun moral. ${ }^{9}$

Akta otentik berdasarkan Pasal 1868 KUHPerdata adalah, "suatu akta otentik adalah suatu akta yang di dalam bentuknya yang ditentukan oleh undang-undang dibuat oleh atau di hadapan pegawai-pegawai umum yang berkuasa untuk itu di tempat dimana akta dibuatnya." Maka unsur-unsur yang terdapat dalam Pasal 1868 KUHPerdata adalah bahwa akta itu: (1) dibuat dan diresmikan dalam bentuk yang ditentukan undang-undang; (2) dibuat oleh atau di hadapan pejabat umum; (3) dibuat di hadapan yang berwenang untuk membuatnya di tempat dimana akta dibuat.

Menurut Pasal 1869 KUHPerdata menyebutkan bahwa, suatu akta yang tidak dapat diperlakukan sebagai akta otentik, "baik karena tidak berwenang atau tidak cakapnya pejabat umum yang bersangkutan maupun karena cacat dalam bentuknya, mempunyai kekuatan sebagai tulisan di bawah tangan bila ditandatangani oleh para pihak." Sangat penting dan patut diperhatikan apakah akta otentik yang selama ini digunakan pada praktik perbankan syariah telah memenuhi ketentuan yang sesuai dengan ketentuan Pasal 38 Undang-Undang Jabatan Notaris. Terlebih, dengan adanya fenomena serba syariah ini, tidak jarang pada akta dicantumkan kutipan dari ayat Al-Quran. Pencantuman kutipan ayat Al-Quran tersebut menjadi tanda tanya apakah dapat menggugurkan keotentikan dari akta yang dibuat oleh Notaris. Maka jangan sampai bentuk dan sifat akta yang digunakan pada praktik perbankan syariah tidak sesuai dengan ketentuan pasal tersebut, sehingga sifat otentik pada akta itu turun derajatnya menjadi suatu akta di bawah tangan saja.

\section{Rumusan Masalah}

Berdasarkan uraian latar belakang di atas, selanjutnya dapat dirumuskan permasalahan sebagai berikut: pertama, bagaimana implikasi yuridis terhadap keabsahan akta yang dibuat oleh Notaris terkait dengan penambahan kutipan

${ }^{9}$ Abdul Ghofur Anshori, Lembaga Kenotariatan Indonesia; Perspektif Hukum dan Etika, UII Press, Yogyakarta, 2012, hlm. 43. 
ayat Al-Quran pada akta berdasarkan Undang-Undang Jabatan Notaris? Kedua, bagaimana formulasi mengenai sistematika akta Notaris dalam akad syariah yang berkepastian hukum?

\section{Tujuan Penelitian}

Adapun tujuan yang hendak dicapai melalui penelitian ini adalah sebagai berikut: pertama, untuk mendeskripsikan dan menganalisis implikasi yuridis terhadap keabsahan akta yang dibuat oleh Notaris terkait dengan penambahan kutipan ayat al-Qur'an pada akta berdasarkan peraturan perundang-undangan jabatan Notaris. Kedua, untuk mendeskripsikan dan menganalisis formulasi mengenai sistematika akta Notaris dalam akad syariah yang berkepastian hukum.

\section{Metode Penelitian}

Jenis penelitian yang akan digunakan dalam penelitian ini adalah penelitian yuridis empiris, yaitu penelitian hukum mengenai pemberlakuan atau implementasi ketentuan hukum normatif secara perilaku nyata pada setiap peristiwa hukum yang terjadi dalam masyarakat. Penelitian ini didasarkan pada penelitian kepustakaan tetapi untuk melengkapi data yang diperoleh dari penelitian kepustakaan, dilakukan penelitian lapangan. Hal ini dilakukan karena penelitian kepustakaan untuk lengkapnya perlu didukung dengan penelitian lapangan. Oleh karena itu penelitian ini menggunakan dua jenis penelitian hukum, yaitu penelitian kepustakaan dan penelitian lapangan. Penelitian kepustakaan untuk memperoleh data sekunder dan penelitian lapangan untuk memperoleh data primer. $^{10}$

\section{Hasil Penelitian dan Pembahasan}

Implikasi Yuridis Keabsahan Akta yang Dibuat oleh Notaris Terkait dengan Penambahan Kutipan Ayat Al-Quran Berdasarkan Perundang-undangan Jabatan Notaris

Pasal 38 ayat (2) huruf d Undang-Undang Jabatan Notaris (UUJN) menegaskan bahwa pada awal atau kepala akta memuat nama lengkap dan tempat kedudukan Notaris. Kemudian berdasarkan Pasal 44 ayat (1) UUJN pada akhir akta wajib dicantumkan tanda tangan Notaris. Pencantuman nama dan tanda tangan Notaris pada akhir akta merupakan perintah UUJN, karena merupakan bagian dari syarat formal akta Notaris. Kemudian, jika syarat formal tidak dipenuhi, baik sebagian atau seluruhnya sebagaimana diisyaratkan Pasal 38 UUJN, maka akta Notaris tersebut hanya mempunyai akta pembuktian

${ }^{10}$ Soerjono Soekanto, Pengantar Penelitian Hukum, Universitas Indonesia, Jakarta, 1986, hlm. 51. 
sebagaimana disebutkan dalam Pasal 38 UUJN dan juga kekuatan pembuktian sebagai tulisan di bawah tangan jika ditandatangani oleh para pihak sebagaimana juga ditegaskan dalam Pasal 1869 KUHPerdata. ${ }^{11}$

Menjadi kewajiban dan tanggungjawab Notaris untuk memenuhi semua aspek formalitas akta Notaris, yaitu:

a. awal akta.

b. isi akta (substansi kehendak para pihak).

c. akhir akta.

Pemenuhan semua aspek pada awal akta sampai akhir akta mutlak tanggungjawab Notaris. Undang-Undang Jabatan Notaris memberikan sanksi terhadap Notaris dan kedudukan hukum akta yang tidak sesuai dengan ketentuan Pasal 38 UUJN. Terkait hal tersebut, Pasal 41 UUJN menyebutkan tentang, "pelanggaran terhadap ketentuan sebagaimana dimaksud dalam Pasal 38, Pasal 39, dan Pasal 40 mengakibatkan akta hanya mempunyai kekuatan pembuktian sebagai akta di bawah tangan."12

Jika para pihak yang tersebut namanya dalam akta yang bersangkutan, yang seharusnya tindakan hukumnya terlindungi, dilindungi oleh/dalam akta tersebut, tapi karena kesalahan Notaris dari aspek formal maka menjadi terdegradasi kedudukannya menjadi akta yang mempunyai kekuatan pembuktian sebagai akta di bawah tangan. Apabila para pihak atau klien merasa dirugikan secara materil, terhadap Notaris dapat diajukan tuntutan/gugatan ganti kerugian ke pengadilan negeri. Namun, selama tidak ada yang merasa keberatan dengan bentuk akta yang demikian maka akta tersebut tetap diaggap sebagai suatu akta otentik. ${ }^{13}$

Jika terbukti dan pengadilan mewajibkan kepada Notaris untuk membayar ganti rugi tersebut, dan ternyata Notaris tidak mampu membayarnya maka atas hal tersebut Notaris akan dimohonkan pailit oleh yang bersangkutan. Notaris yang dinyatakan pailit berdasarkan ketentuan Pasal 12 UUJN disebutkan bahwa, "Notaris diberhentikan dengan tidak hormat dari jabatannya oleh Menteri atas usul Majelis Pengawas Pusat apabila dinyatakan pailit berdasarkan putusan pengadilan yang telah memperoleh kekuatan hukum tetap."14 Oleh sebab itu, dalam pembuatan akta-akta perbankan syariah yang dibuat dalam bentuk akta

\footnotetext{
${ }^{11}$ Habib Adjie, Kebatalan Dan Pembatalan Akta Notaris, Cetakan Ketiga, PT. Refika Aditama, Bandung, 2015, hlm. 1.

${ }^{12}$ Lihat di dalam Pasal 41 Undang-Undang Nomor 2 Tahun 2014 tentang Perubahan Atas UndangUndang Nomor 30 Tahun 2004 tentang Jabatan Notaris.

${ }^{13}$ Hasil wawancara dengan Habib Adjie, Sekretaris Dewan Kehormatan Pusat Ikatan Notaris Indonesia (DKP INI) periode 2016-2019, Akademisi, Penulis buku di bidang Kenotariatan, Notaris/PPAT, Pejabat Lelang Kelas II Kota Surabaya, 27 Maret 2021.

${ }^{14}$ Lihat di dalam Pasal 12 huruf a Undang-Undang Nomor 2 Tahun 2014 tentang Perubahan Atas Undang-Undang Nomor 30 Tahun 2004 tentang Jabatan Notaris.
} 
Notaris harus berdasarkan atau dibuat dalam bentuk akta Notaris sesuai dengan formalitas akta Notaris yang diatur dalam Pasal 38 UUJN.

Apabila para pihak atau klien meminta untuk ditambahkannya ayat-ayat AlQuran ke dalam akta otentik atau akta Notaris maka perlu diperhatikan oleh Notaris di dalam penempatan ayat tersebut supaya tidak menyalahi ketentuan Pasal 38 UUJN. Penggunaan ayat tersebut dapat ditempatkan di awal isi akta dan di akhir isi akta. Akta Notaris sebagai alat bukti agar mempunyai kekuatan pembuktian yang sempurna jika seluruh ketentuan prosedur atau tata cara pembuatan akta dipenuhi. Apabila ada prosedur yang tidak dipenuhi dan prosedur tersebut dapat dibuktikan, akta tersebut dengan proses pengadilan dapat dinyatakan sebagai akta yang mempunyai kekuatan pembuktian di bawah tangan. Jika sudah berkedudukan seperti itu, nilai pembuktiannya diserahkan kepada hakim. ${ }^{15}$

Menurut hasil pengamatan Penulis di lapangan, masih ditemukan akad perbankan syariah yang isinya tidak sepenuhnya melaksanakan prinsip syariah. Ada baiknya Notaris tidak hanya memperhatikan bentuk dari akta perjanjian syariah namun juga memperhatikan dan menilai materi dari akad perjanjian syariah apakah sudah sepenuhnya menerapkan prinsip-prinsip syariah yang baik dan benar sehingga semua yang terlibat di dalamnya mendapat berkah. Hal yang demikian yang sebenarnya lebih baik untuk diperhatikan atau menjadi perhatian bersama, dimana penegakan prinsip syariah yang baik dan benar merupakan hal yang sangat penting.

\section{Formulasi Mengenai Sistematika Akta Notaris dalam Akad Syariah yang Berkepastian Hukum}

Berdasarkan ketentuan Pasal 1 angka 12 Undang-Undang Nomor 10 Tahun 1998 tentang Perubahan Atas Undang-Undang Nomor 7 Tahun 1992 tentang Perbankan menyebutkan bahwa, "Pembiayaan berdasarkan prinsip syariah adalah penyediaan uang atau tagihan yang dipersamakan dengan itu berdasarkan persetujuan atau kesepakatan antara bank dengan pihak lain yang mewajibkan pihak yang dibiayai untuk mengembalikan uang atau tagihan tabungan setelah jangka waktu tertentu dengan imbalan atau bagi hasil."16

Pembiayaan berdasarkan prinsip syariah dituangkan dalam bentuk perjanjian pembiayaan, perjanjian pembiayaan ini dibuat dalam bentuk akta otentik. Perjanjian pembiayaan yang dituangkan dalam bentuk akta otentik membutuhkan peran Notaris dalam proses pembuatannya. Akad pada bank

${ }^{15}$ Habib Adjie dan Muhammad Hafidh, Akta Notaris Untuk Perbankan Syariah, Cetakan Pertama, Bandung, PT. Citra Aditya Bakti, 2017, hlm. 36.

${ }^{16}$ Lihat di dalam Pasal 1 angka 12 Undang-Undang Nomor 10 Tahun 1998 tentang Perubahan Atas Undang-Undang Nomor 7 Tahun 1992 tentang Perbankan. 
syariah yang berbentuk akta Notaris tetap harus memperhatikan tentang maisir ${ }^{17}$, gharar $^{18}$, dan riba ${ }^{19}$ (magrhrib) dan asas-asas perjanjian (akad) dalam akta Notaris perbankan syariah dalam kata/kalimat serta substansinya.

Akta yang dibuat di hadapan atau oleh Notaris berkedudukan sebagai akta otentik menurut bentuk dan tata cara yang ditetapkan dalam UUJN. ${ }^{20}$ Hal ini sejalan dengan pendapat Philipus M. Hadjon, bahwa syarat akta otentik, yaitu:

1. Di dalam bentuk yang ditentukan oleh undang-undang (bentuknya baku);

2. Dibuat oleh dan di hadapan pejabat umum. ${ }^{21}$

Dikemukakan pula oleh Irawan Soerodjo, bahwa ada 3 unsur esenselia agar terpenuhinya syarat formal suatu akta otentik, yaitu:

1. Dalam bentuk yang ditentukan oleh undang-undang.

2. Dibuat oleh dan di hadapan pejabat umum.

3. Akta yang dibuat oleh atau di hadapan pejabat umum yang berwenang untuk itu dan di tempat dimana akta itu dibuat. ${ }^{22}$

Pasal 1868 Kitab Undang-Undang Hukum Perdata merupakan sumber untuk otensitas akta Notaris juga merupakan dasar legalitas eksistensi akta Notaris, dengan syarat-syarat sebagai berikut:

1. Akta itu harus dibuat oleh (door) atau di hadapan (ten overstan) seorang pejabat umum.

2. Akta itu harus dibuat dalam bentuk yang ditentukan oleh undang-undang.

3. Pejabat umum oleh atau dihadapan siapa akta itu dibuat, harus mempunyai wewenang untuk membuat akta tersebut.

Sebagai bahan perbandingan, berdasarkan ketentuan Pasal 38 UUJN maka anatomi akta terdiri atas;

1. Kepala (hoofd) Akta

Yang memuat keterangan-keterangan dari Notaris mengenai dirinya dan orang-orang yang datang menghadap kepadanya atau atas permintaan siapa dibuat berita acara.

a. judul akta;

b. nomor akta;

\footnotetext{
${ }^{17}$ Maisir adalah suatu kegiatan bisnis yang di dalamnya jelas bersifat untung-untungan atau spekulasi yang tidak rasional, tidak logis, tak jelas barang yang ditawarkan baik secara kuantitatif maupun secara kualitatif.

${ }^{18}$ Gharar adalah suatu kegiatan bisnis yang tidak jelas kuantitas, kualitas, harga dan waktu terjadinya transaksi tidak jelas.Aktivitas bisnis yang mengandung gharar adalah bisnis yang mengandung risiko tinggi, atau transaksi yang dilakukan dalam bisnis tak pasti atau kepastian usaha ini sangat kecil dan risikonya cukup besar.

${ }^{19}$ Riba adalah Kelebihan/tambahan pembayaran tanpa ada ganti/imbalan yang disyaratkan bagi salah seorang dari dua orang yang membuat akad (transaksi).

${ }^{20}$ Lihat di dalam Pasal 1 angka 7 Undang-Undang Nomor 2 Tahun 2014 tentang Perubahan Atas Undang-Undang Nomor 30 Tahun 2004 tentang Jabatan Notaris. 3.

${ }_{21}$ Philipus M. Hadjon, Formulir Pendaftaran Tanab Bukan Akta Otentik, Surabaya Post, Surabaya, 2001, hlm.

${ }^{22}$ Irawan Soerodjo, Kepastian Hukum Hak. Atas Tanah di Indonesia, Arkola, Surabaya, 2003, hlm. 148.
} 
c. pukul, hari, tanggal, bulan, dan tahun;

d. nama lengkap dan tempat kedudukan Notaris, dan wilayah jabatan Notaris;

e. nama lengkap, tempat dan tanggal lahir, kewarganegaraan, pekerjaan, jabatan, kedudukan, tempat tinggal para penghadap dan/atau orang yang mereka wakili;

f. keterangan mengenai kedudukan bertindak menghadap; dan

g. nama lengkap, tempat tanggal lahir, serta pekerjaan, jabatan, kedudukan, dan tempat tinggal dari tiap-tiap saksi pengenal.

2. Badan Akta

Yang memuat keterangan-keterangan yang diberikan oleh pihak-pihak dalam akta atau keterangan-keterangan dari Notaris mengenai hal-hal yang disaksikannya atas permintaan yang bersangkutan.

3. Penutup Akta

Yang memuat keterangan dari Notaris mengenai waktu dan tempat akta dibuat. Selanjutnya, keterangan mengenai saksi-saksi, di hadapan siapa akta dibuat, dan akhirnya tentang pembacaan dan penandatanganan dari akta ini.

Dalam Pasal 1 angka 13 Undang-Undang Nomor 21 Tahun 2008 tentang Perbankan Syariah ditegaskan bahwa aqad adalah kesepakatan tertulis. Pasal ini hanya mewajibkan akad ataupun akta dalam perbankan syariah harus tertulis, tidak mewajibkan dalam bentuk tertentu. Untuk isi atau substansi dari kesepakatan tertulis tersebut memuat adanya hak dan kewajiban bagi masingmasing pihak sesuai dengan prinsip syariah.

Dalam praktik perbankan syariah ${ }^{23}$ atau Unit Usaha Syariah (UUS) ${ }^{24}$ kesepakatan tertulis tersebut ada yang dibuat dalam bentuk akta Notaris sehingga untuk membedakan antara akta perbankan syariah dan perbankan konvensional,25 yang dibuat dengan akta Notaris pada awal aktanya dicantumkan kalimat tertentu, seperti penggunaan ayat-ayat al-Qur'an atau

23Pasal 1 angka 7, 8, dan 9 Undang-Undang Nomor 21 Tahun 2008 tentang Perbankan Syariah menyebutkan bahwa: (7) berdasarkan prinsip syariah dan menurut jenisnya terdiri atas Bank Umum Syariah dan Bank Pembiayaan Syariah, (8) Bank Umum Syariah adalah bank syariah yang dalam kegiatannya memberikan jasa dalam lalu lintas pembayaran, (9) Bank Pembiayaan Syariah adalah bank syariah yang dalam kegiatannya tidak memberikan jasa dalam lalu lintas pembayaran.

${ }^{24}$ Unit Usaha Syariah, yang selanjutnya disebut UUS, adalah unit kerja dari kantor pusat Bank Umum Konvensional yang berfungsi sebagai kantor induk dari kantor atau unit yang melaksanakan kegiatan usaha berdasarkan Prinsip Syariah, atau unit kerja di kantor cabang dari suatu Bank yang berkedudukan di luar negeri yang melaksanakan kegiatan usaha secara konvensional yang berfungsi sebagai kantor induk dari kantor cabang pembantu syariah dan/atau unit syariah.

25Dalam Pasal 1 angka 4, 5, dan 6 Undang-Undang Nomor 21 Tahun 2008 tentang Perbankan Syariah disebutkan: (4) Bank Konvensional adalah Bank yang menjalankan kegiatan usahanya secara konvensional dan berdasarkan jenisnya terdiri atas Bank Umum Konvensional dan Bank Perkreditan Rakyat. (5) Bank Umum Konvensional adalah Bank Konvensional yang dalam kegiatannya memberikan jasa dalam lalu lintas pembayaran. (6) Bank Perkreditan Rakyat adalah Bank Konvensional yang dalam kegiatannya tidak memberikan jasa dalam lalu lintas pembayaran. 
hadits-hadits. Hal yang demikian, merupakan permintaan dari para pihak yang terkait di dalam akta tersebut dengan alasan supaya ada pembedaan dengan aktaakta yang biasa digunakan pada perbankan konvensional. ${ }^{26}$

Jika awal akta perbankan syariah dalam bentuk akta Notaris dengan awal akta seperti tersebut di atas, awal akta tersebut tidak sesuai dengan Pasal 38 ayat (2) Undang-Undang Nomor 2 Tahun 2014 tentang Perubahan Atas UndangUndang Nomor 30 Tahun 2004 tentang Jabatan Notaris. Sebagaimana telah diuraikan sebelumnya bahwa awal akta Notaris terdiri atas:
a. judul akta;
b. nomor akta;
c. jam, hari, tanggal, bulan, tahun; dan
d. nama lengkap dan tempat kedudukan Notaris.

Akta syariah yang saat ini biasa digunakan (penambahan ayat-ayat AlQuran serta hadits-hadits) belum diatur di dalam Undang-Undang Jabatan Notaris maupun di Kompilasi Hukum Islam. Apabila kita berbicara tentang ketentuan di dalam ruang lingkup hukum kenotariatan, kita bisa merujuk pada contoh penerapan aturan yang pernah dilakukan pada saat kongres Notaris Ikatan Notaris Indonesia, yang menetapkan bahwa kewajiban bagi Notaris untuk menggunakan kalimat "menghadap kepada saya" di dalam setiap pembuatan akta otentik. Kemudian, yang berkaitan dengan formula atau ketentuan baru mengenai bentuk akta perjanjian syariah hingga saat ini belum pernah dilakukan. Pasal 38 UUJN tidak merumuskan secara detail bahwa penambahan ayat-ayat AlQuran merupakan suatu pelanggaran ketentuan UUJN. Hal tersebut masih menjadi sebuah perdebatan. ${ }^{27}$

Pencantuman ayat-ayat Al-Quran serta hadits-hadits seperti tersebut pada awal dan di akhir akta perbankan syariah menjadi tanda tanya apakah dapat menggugurkan keotentikan dari akta yang dibuat oleh Notaris sebab tidak sesuai bentuknya dengan ketentuan Pasal 38 UUJN. Yang menjadi fokus di sini adalah bukan penggunaan ayat-ayat Al-Quran serta hadits-haditsnya, tetapi penampatan ayat-ayat tersebut yang diletakkan di awal dan akhir akta lah yang dianggap tidak selaras dengan Pasal 38 UUJN. Sejatinya, penambahan ayat-ayat Al-Quran serta hadits-hadits di dalam akta perjanjian syariah baik adanya. ${ }^{28}$

Pada dasarnya pencantuman kalimat tersebut ditempatkan pada awal isi akta. Dengan pencantuman dan penempatan kalimat sebagaimana tersebut pada

${ }^{26}$ Hasil wawancara dengan salah satu Notaris di Kota Makassar yang menjadi rekanan perbankan syariah, 19 Maret 2021.

${ }^{27}$ Hasil wawancara dengan salah satu Notaris di Kabupaten Boyolali yang menjadi rekanan perbankan syariah, 30 Maret 2021.

${ }^{28}$ Hasil wawancara salah satu Notaris di Balikpapan yang menjadi rekanan perbankan syariah, 2 April 2021. 
awal isi akta perbankan syariah, maka secara formalitas akta Notaris telah sesuai dengan Pasal 38 ayat (3) huruf c Undang-Undang Nomor 2 Tahun 2014 tentang Perubahan Atas Undang-Undang Nomor 30 Tahun 2004 tentang Jabatan Notaris: (isi akta yang merupakan kehendak dan keinginan dari pihak yang berkepentingan). ${ }^{29}$

Pencantuman kalimat ayat-ayat Al-Quran atau hadits-hadits dalam akta perbankan syariah yang dibuat oleh Notaris harus diperhatikan oleh Notaris sebab menurut Penulis, apabila pencantuman kalimat ayat-ayat Al-Quran atau hadits-hadits tersebut tidak memperhatikan ketentuan undang-undang maka akan dapat menggugurkan keotentikan akta tersebut. Undang-Undang Jabatan Notaris memeberikan sanksi terhadap Notaris dan kedudukan hukum akta yang tidak sesuai dengan ketentuan Pasal 38 UUJN. Terkait hal tersebut, Pasal 41 UUJN menyebutkan tentang, "Pelanggaran terhadap ketentuan sebagaimana dimaksud dalam Pasal 38, Pasal 39, dan Pasal 40 mengakibatkan akta hanya mempunyai kekuatan pembuktian sebagai akta di bawah tangan."

\section{Penutup}

Penggunaan kutipan ayat Al-Quran serta hadits-hadits pada akta perbankan syariah sudah sesuai ketentuan peraturan perundang-undangan yakni Pasal 38 Undang-Undang Jabatan Notaris sebagai acuan dari bentuk akta otentik. Penggunaan kutipan ayat Al-Quran demikian tidak melanggar ketentuan perundang-undangan apabila diletakkan pada awal isi akta atau pada akhir premisse. Bahwa awal dan akhir akta mutlak merupakan tanggung jawab Notaris. Namun untuk isi akta merupakan kesepakatan tertulis yang dikehendaki oleh para pihak selama/sepanjang berdasarkan peraturan perundang-undangan yang berlaku atau sesuai prinsip syariah.

Pembuatan akta-akta perbankan syariah yang dibuat dalam bentuk akta Notaris harus berdasarkan atau dibuat dalam bentuk akta Notaris sesuai dengan formalitas akta Notaris yang diatur dalam Pasal 38 UUJN. Akta Notaris sebagai alat bukti agar mempunyai kekuatan pembuktian yang sempurna jika seluruh ketentuan prosedur atau tata cara pembuatan akta dipenuhi. Apabila ada prosedur yang tidak dipenuhi dan prosedur tersebut dapat dibuktikan, akta tersebut dengan proses pengadilan dapat dinyatakan sebagai akta yang mempunyai kekuatan pembuktian di bawahtangan. Jika sudah berkedudukan seperti itu, nilai pembuktiannya diserahkan kepada hakim. Apabila para pihak atau klien meminta untuk ditambahkannya ayat-ayat Al-Quran ke dalam akta

${ }^{29}$ Habib Adjie dan Muhammad Hafidh, Akta Notaris Untuk Perbankan Syariah, Cetakan Pertama, PT. Citra Aditya Bakti, Bandung, 2017, hlm. 67. 
otentik atau akta Notaris maka perlu diperhatikan oleh Notaris di dalam penempatan ayat tersebut supaya tidak menyalahi ketentuan Pasal 38 UUJN. Penggunaan ayat tersebut dapat ditempatkan di awal isi akta dan di akhir isi akta.

Notaris sebagai pejabat umum yang diberikan kewenangan oleh negara untuk membuat akta otentik sudah seharusnya memperhatikan ketentuanketentuan untuk menjamin terpenuhinya syarat-syarat formil akta yang dibuatnya, guna menjamin keotentikan akta yang dibuatnya. Sehingga di kemudian hari tidak ada yang dirugikan akibat gugurnya keotentikan akta akibat tidak terpenuhinya syarat formil akta Notaris tersebut. Namun dalam hal ini, Notaris tidak hanya memperhatikan dan memastikan dari bentuk akta perjanjian syariah yang dibuat namun juga lebih memperhatikan dan menilai materi dari akad perjanjian syariah apakah sudah sepenuhnya menerapkan prinsip-prinsip syariah yang baik dan benar sehingga semua yang terlibat di dalamnya mendapat berkah. Hal yang demikian yang sebenarnya lebih baik untuk diperhatikan atau menjadi perhatian bersama, dimana penegakan prinsip syariah yang baik dan benar merupakan hal yang sangat penting.

\section{Daftar Pustaka}

\section{Buku}

Adjie, Habib, Kebatalan Dan Pembatalan Akta Notaris, Cetakan Ketiga, PT. Refika Aditama, Bandung, 2015.

dan Muhammad Hafidh, Akta Notaris Untuk Perbankan Syariah, Cetakan Pertama, PT. Citra Aditya Bakti, Bandung, 2017.

Arief, Saifuddin, Notariat Syariah Dalam Praktik, Darunnajah Publishing, Jakarta, 2011.

Direktorat Perbankan Syariah Bank Indonesia, Laporan Perkembangan Perbankan Syariah Tahun 2004, Bank Indonesia, Jakarta, 2004.

Ghofur Anshori, Abdul, Lembaga Kenotariatan Indonesia; Perspektif Hukum dan Etika, UII Press, Yogyakarta, 2012.

Luthfan Hadi Darus, Muhammad, Hukum Notariat dan Tanggung Jawab Jabatan Notaris, UII Press, Yogyakarta, 2017.

M. Hadjon, Philipus, Formulir Pendaftaran Tanah Bukan Akta Otentik, Surabaya Post, Surabaya, 2001

Mahmud, Amir dan Rukmana, Bank Syariah Teori, Kebijakan, dan Studi, Erlangga, Jakarta, 2010.

Soekanto, Soerjono, Pengantar Penelitian Hukum, Universitas Indonesia, Jakarta, 1986.

Soerodjo, Irawan, Kepastian Hukum Hak Atas Tanah di Indonesia, Arkola, Surabaya, 2003. 


\section{Peraturan Perundang-undangan}

Undang-Undang Nomor 10 Tahun 1998 tentang Perubahan Atas Undang-Undang Nomor 7 Tahun 1992 tentang Perbankan

Undang-Undang Nomor 21 Tahun 2008 tentang Perbankan Syariah

Undang-Undang Nomor 2 Tahun 2014 tentang Perubahan Atas Undang-Undang Nomor 30 Tahun 2004 tentang Jabatan Notaris

\section{Wawancara}

Hasil wawancara dengan salah satu Notaris di Kota Makassar yang menjadi rekanan perbankan syariah, 19 Maret 2021

Hasil wawancara dengan salah satu Notaris di Kabupaten Boyolali yang menjadi rekanan perbankan syariah, 30 Maret 2021.

Hasil wawancara salah satu Notaris di Balikpapan yang menjadi rekanan perbankan syariah, 2 April 2021 